\author{
Izabela Kozera \\ Uniwersytet Jagielloński (Kraków, Polska)
}

\title{
СЕМАНТИЧЕСКАЯ ХАРАКТЕРИСТИКА РУССКОГО ГЛАГОЛА ПО ДАННЫМ НКРЯ
}

Настоящая статья посвящена семантическим параметрам, используемым при поиске глаголов в Национальном корпусе русского языка (НКРЯ) - наиболее представительном корпусе текстов современного русского языка.

\section{1. ВВЕДЕНИЕ. ТЕОРЕТИЧЕСКАЯ ОСНОВА ИССЛЕДОВАНИЯ}

Глагол является знаменательной частью речи, которая называет действие, состояние или процесс и выражает это значение в категориях вида, залога, наклонения, времени и лица. «Сложность семантики глаголов затрудняет их классификацию, которая должна исходить из учета характера смысловых связей между отдельными глаголами внутри каждого их класса. Объединение же в группировку или класс, представляя собой ступень обобщения, осуществляется на основании единого семантического признака [...]» (Дрозд 2013: 37-38).

В большинстве работ по грамматике русского языка выделяются семантические разряды глаголов, которые могут быть сведены к двум принципам - хроноструктурным и тематическим (Дрозд 2013: 38). Хроноструктурный критерий связан со способом протекания глагольного действия (т.е. выделяются глаголы действия, состояния, процесса, или согласно известной концепции 3. Вендлера 4 глагольных класса: глаголы типа states, activities, accomplichments, achievements) (Гиро-Вебер 1990, веб-издание). Однако указанное является исходной точкой для исследований в области аспектологии. В настоящей статье внимание уделяется тематическому критерию деления глаголов. На основании литературы вопроса (в частности, работ Васильева 1981, 1990; Золотовой 1982; Чепасовой, Казачук 2007; Бабенко 2009) следует утверждать, что количество семантических типов достаточно неопределенно, но в какой-то степени они совпадают по глагольному составу (сопоставление разных разрядов глаголов представлено в Таб. 1). 
Таб. 1. Семантические типы глаголов

\begin{tabular}{|c|c|c|}
\hline $\begin{array}{c}\text { Васильев Л.М. } \\
\text { 1990, Современная } \\
\text { лингвистическая } \\
\text { семантика, Москва, } \\
\text { с. 119-123. }\end{array}$ & $\begin{array}{c}\text { Золотова Г.А. 1982, } \\
\text { Коммуникативные } \\
\text { аспекты русского } \\
\text { синтаксиса, Москва, } \\
\text { с. 156-168. }\end{array}$ & $\begin{array}{c}\text { Чепасова А.М, Казачук } \\
\text { И.Г. 2007, Глаголы } \\
\text { в современном русском } \\
\text { языке, Москва, с. 20-21. }\end{array}$ \\
\hline $\begin{array}{l}\text { 1. Критерий - } \\
\text { доминирующий } \\
\text { лексический компонент } \\
\text {-бытийность/ } \\
\text { акциональность } \\
\text { 2. Критерий - ядерный } \\
\text { идентифицирующий } \\
\text { компонент }\end{array}$ & $\begin{array}{l}\text { Критерий: } \\
\text { акциональность/ } \\
\text { неакциональность }\end{array}$ & $\begin{array}{l}\text { Критерий - ядерный } \\
\text { компонент }\end{array}$ \\
\hline $\begin{array}{l}\text { 1.1. бытийные: собственно } \\
\text { бытийные } \\
\text { 1.2. глаголы абстрактного } \\
\text { бытия/ биологического } \\
\text { существования }\end{array}$ & $\begin{array}{l}\text { 1. неакциональные: } \\
\text { экзистенциальные глаголы }\end{array}$ & 1. глаголы бытия \\
\hline $\begin{array}{l}\text { 2.1. бытийные: бытийно- } \\
\text { статальные } \\
\text { 2.2. стативы }\end{array}$ & $\begin{array}{l}\text { 2. неакциональные: } \\
\text { статуальные глаголы }\end{array}$ & 2. глаголы становления \\
\hline $\begin{array}{l}\text { 3.1. акциональные } \\
\text { 3.2. физической, } \\
\text { речемыслительной } \\
\text { и психической } \\
\text { деятельности/ конкретного } \\
\text { действия/ акционально- } \\
\text { процессуальные }\end{array}$ & $\begin{array}{l}\text { 3. акциональные: глаголы } \\
\text { рече-мыслительного } \\
\text { действия, эмоционального } \\
\text { действия, конкретного } \\
\text { физического действия, } \\
\text { социативного или } \\
\text { интерсубъектного действия, } \\
\text { глаголы движения }\end{array}$ & $\begin{array}{l}\text { 3. глаголы действия / } \\
\text { деятельности }\end{array}$ \\
\hline $\begin{array}{l}\text { 4.1. бытийные: бытийно- } \\
\text { локативные } \\
\text { 4.2. предикаты положения } \\
\text { в пространстве (локативы) }\end{array}$ & $\begin{array}{l}\text { 4. неакциональные: } \\
\text { локализующего значения }\end{array}$ & 4. действенного состояния \\
\hline $\begin{array}{l}\text { 5.1. бытийные: бытийно- } \\
\text { релятивные (предикаты } \\
\text { отношения) } \\
\text { 5.2. предикаты отношения } \\
\text { (релятивы) / посессивы/ } \\
\text { компаративы/ партитивы }\end{array}$ & $\begin{array}{l}\text { 5. неакциональные: } \\
\text { глаголы со значением } \\
\text { партитивности, } \\
\text { посессивности отношений, } \\
\text { глаголы компаративного/ } \\
\text { сопоставительного значения }\end{array}$ & 5. глаголы отношения \\
\hline
\end{tabular}

Источник: собственный материал.

В настоящем сопоставлении самая ранняя типология глаголов представлена в работах Л. М. Васильева (1981, 1990). В ее основе лежит структурное членение семемы. Согласно Л. М. Васильеву, «типы [глагольных - И. К.] 
значений (семем) определяются в первую очередь их функциями и их структурой, т.е. характером входящих в их состав компонентов и их взаимоотношением, их иерархией (...)» (Васильев 1981: 21). В состав иерархической структуры семемы (значения) входят доминирующие и зависимые (подчиненные) семантические компоненты (там же: 23). Пересекаемость глагольных парадигм позволяет выделять ядерные и периферийные компоненты (там же). Итак, компонент «говорить» для глагола разговаривать является ядерным, а компонент «взаимный речевой акт» - периферийным (там же). Указанные компоненты могут дополнительно исполнять идентифицирующую или дифференцирующую функции в зависимости от семантической парадигмы (там же). Итак, компонент «быстро» по отношению к парадигме «говорить» является дифференцирующим, но для парадигмы «мчаться» уже идентифицирующим (там же: 24).

Выделенные Л. М. Васильевым (1981) глаголы различаются по денотативному (тематическому), парадигматическому (выделение тождественных и дифференциальных компонентов) и синтагматическому принципам (учет глагольных валентностей) (там же: 39). По доминирующим лексическим компонентам семем выделяются два основных типа предикатов: бытийные и акциональные (Васильев 1990: 119). Среди бытийных глаголов выделяются: собственно бытийные и событийные (быть, существовать, случаться, происходить, иметь место); бытийно-релятивные (предикаты отношения): соответствовать, равняться, принадлежать; бытийно-квалификативные (предикаты свойства и количества), бытийно-оценочные, бытийно-генеративные (звучать, звенеть, белеться); бытийно-статальные (предикаты состояния): спать, дрожать, тосковать, радоваться; бытийно-локативные (предикаты положения в пространстве): находиться, присутствовать, оставаться; бытийно-акциональные (предикаты деятельности): заниматься, учительствовать, бездельничать; бытийно-функциональные (предикаты функционирования): мотор работает, сердие бьется (там же: 119-120).

Акциональные предикаты «по доминирующему компоненту 'осуществлять, совершать какое-либо действие, делать что-либо' или по тому же самому компоненту с отрицанием» (там же: 119) представлены глаголами действия, воздействия, движения и психофизиологических процессов (делать, создавать, думать, разговаривать, толкать, идти, вести, видеть, сльлиать, дылиать и т.п.) (там же: 121). По второму критерию - ядерному идентифицирующему компоненту - выделяются следующие семантические классы глаголов: 1) бытийные и событийные предикаты: а) абстрактного бытия: быть, существовать, появляться, возникать, оказываться, происходить, случаться; б) биологического существования: жить, расти, рождаться, умирать; в) фазисные предикаты: начинать, кончать, продолжать, длиться, оставаться; 2) предикаты отношения (релятивы): а) абстрактные релятивы: зависеть, иметь отношение; б) посессивы: иметь, 
принадлежать, обладать, владеть; в) компаративы: соответствовать, равняться, сравнивать; г) партитивы («выражают отношение целого и части»): состоять из чего-либо, содержать что-либо; 3) предикаты свойства (квалификативы): а) качественные: cmapemь, стариться, старить; б) параметрические («меры множества и величины»): увеличиваться, уменьшать, умножать, расширять; в) предикаты проявления признака или свойства (генеративы): белеться, звучать, звенеть, светить, сиять, блестеть; 4) оценочные предикаты: а) абстрактно-оценочные (предикаты общей оценки); б) модально-оценочные (предикаты возможности, необходимости, желания): мочь, хотеть, желать; в) предикаты мнения: полагать, считать, предполагать; г) предикаты поведения (выражают оценку по поведению): скромничать, мошенничать); 5) предикаты состояния (стативы): а) физического и физиологического: твердеть, мякнуть, размягчаться, хромать, спать, ycыплять, уставать; б) психофизиологического (умственного и эмоционального): быть в своем уме, обезуметь, печалиться, влюбляться; в) социального положения (состояния): богатеть, угнетать); 6) предикаты положения в пространстве (локативы): а) абстрактные: находиться, пребывать, присутствовать; б) пространственно-квалификативные: сидеть, садиться, сажать, лежать); 7) акциональные предикаты а) физической, речемыслительной и психической деятельности (действие или процесс): заниматься чем-либо, учиться, стараться, руководить; б) конкретного действия (физического, умственного, волевого): стучать, пилить, читать, писать, разговаривать; в) воздействия (физического, психического, морального): толкать, сжимать, наказывать, поощрять; г) движения: двигаться, ходить, ездить, летать, падать; д) способности к движению, деятельности: ребенок уже ходит, говорит); 8) акционально-процессуальные: а) чувственного и умственного восприятия: видеть, сльишать, чувствовать, смотреть; б) физиологических процессов: дымшать, зевать; в) психофизиологических процессов: смеяться, плакать; 9) функциональные предикаты: завод работает, часы ходят (Васильев 1990: 121-123)

Схожую классификацию полнозначных глаголов представляет Г. А. Золотова (1982). На основании критерия акциональности/неакциональности исследовательница дает конкретную характеристику семантических классов, которые в большинстве совпадают с классами Л.М. Васильева (1990). Среди акциональных глаголов, обозначающих физические или ментальные действия субъекта (Золотова 1982: 162), перечисляются: а) глаголы рече-мыслительного действия, предполагающие при себе имена адресата и делиберата (объекта, содержания мысли и речи - напр. сообщзить друзьям об

1 Указанная классификация предикатов учитывает не только глаголы, но также другие части речи, исполняющие предикативную функцию. В данном случае вслед за работой Л. М. Васильева (1990) цитируются лишь подходящие глагольные примеры. 
отьезде; рассказать сыну сказку; поздравить коллег с праздником; выступить перед студентами с лекцией); б) глаголы эмоционального действия с указанием на объект действия - типа любить, презирать, злиться; в) глаголы конкретного физического действия с указанием не только на объект, но и факультативно на инструмент/орудие, напр. мешать чай ложечкой; работать на огороде; забивать гвоздь молотком, стирать белье; копать яму; иить блузку; чинить мебель; чистить картошку; г) глаголы социативного или интерсубъектного действия со значением совместного субъекта и цели, напр. бороться с соперниками за кубок, дискутировать с коллегами о пого$\partial e$; д) глаголы движения, открывающие при себе места для имен директивов (старта/финиша), трассы, средства передвижения и включающие глаголы, называющие перемещение, напр. лететь из Москвы в Санкт-Петербург, перейти по мосту с одного берега на другой, пробираться через болота (Золотова 1982: 162-163).

Кроме акциональных глаголов, выделяются также неакциональные глаголы, которые, по мнению Г. А. Золотовой, не соответствуют основному категориальному значению глагола (значению действия) и бывают лексически ослабленными (Золотова 1982: 159). Среди них можно перечислить: а) глаголы локализующего значения, сообщающие пространственное положение предмета, напр. тетрадь лежит на столе, булочная находиться за углом (там же, 159); б) глаголы экзистенциального значения, типа есть (был/будет), имеется, присутствует, которые являются синонимичными по отношению к безглагольным предложениям (там же: 160-161); в) глаголы со значением партитивности, выражающие отношения часть-целое (молоко состоит uз воды) или классификационные отношения (кедр относится к хвойнылм деревьям); г) глаголы со значением посессивности отношений (принадлежности между субъектом и объектом владения), напр. y соседей есть сад = у соседей имеется сад = сад принадлежит соседям (там же: 161); д) глаголы компаративного значения, которые участвуют в предложениях, содержащих сравнение двух предметов или явлений, напр. Тула превосходит Kалугу по численности населения (там же); е) глаголы сопоставительного значения указывают на отношения иерархии и соответствия между предметами или явлениями, напр. работа отвечает требованиям, композиция подчиняется замыслу (там же: 162); ё) статуальные глаголы обозначают состояние или изменение состояния предмета/лица, напр. сирень изветет, зеленеет трава, дети растут, сестра выздоравливает (там же); ж) функтивные глаголы обозначают функционирование предмета, также в значении способа существования, напр. ветер дует, карандаш пишет. К указанным примыкают также глаголы со значением звука, цвета, света, типа перья скрипят, белеют ромашки, мерцают звезды (там же).

Среди новейших трактовок следует обратить внимание на концепцию А. М. Чепасовой и И. Г. Казачук (2007), которые выделяют пять основных 
семантических разрядов глаголов. Характерной чертой является их типологический характер, так как существует возможность включить сему другой категории. Указанные пять типов находятся в сложных взаимодействиях (Чепасова, Казачук 2007: 21), что можно заметить уже на основании перечисленных авторами примеров. Глаголы находиться, располагаться, пребывать причисляются авторами к глаголам бытия (там же: 20). Авторы включают в эту группу также глаголы, которых значение контекстуально обусловлено, - напр. чувствовать (пальцьь не чувствуют), спать (совесть cnum) (там же). По мнению авторов, указанные глаголы обладают ядерной семой, обозначающей внутреннюю статичность факта, события (там же). Ко второй группе - глаголов становления - принадлежат глаголы, характеризирующиеся внутренним развитием, движением, которое может возникать под действием внешней силы (там же). Они определяются авторами как динамические, напр. засылnamb, взрослеть, мокнуть (там же). Самое большое количество глаголов принадлежит к третьей группе - к глаголам действия/деятельности, так как она включает напр. физические действия, мыслительную деятельность человека, движение (ядерная сема действия сочетается с семой бытия) (там же). Глаголы действенного состояния обозначают физическое или психическое состояние живых существ и человека напр. молчать, лежать, также физическое состояние предметов. «Ядерная сема состояния может сочетаться с семой бытия и семой становления» (там же: 21). В пятой группе «Отношения» объединяются глаголы направленного действия, напр. относиться к кому-то, руководить чем-либо.

Большим достижением в области изучения глагольной семантики является учебный словарь-справочник «Лексико-семантические группы русских глаголов» (1988), который был разработан научным коллективом Уральского университета, в частности Э. В. Кузнецовой, которая уже в начале 70-х годов создала методику идентификации словарных значений глаголов (БТСЛ: 11)2. В этом словаре анализируются 2500 общеупотребительных глаголов (там же). Благодаря работе межвузовской проблемной группы «Русский глагол», состоящей из лингвистов-преподавателей вузов г. Екатеринбурга (там же), были в дальнейшем изданы «Толковый тематический словарь русских глаголов» (1999) под редакцией Л. Г. Бабенко и его новейшее издание «Большой толковый словарь русских глаголов» (2009), пополненное новыми словарными статьями глаголов (там же, 12). В указанном словаре выделяются три основных класса глаголов - I. ДЕЙСТВИЕ и ДЕЯТЕЛЬНОСТЬ, ІІ. БЫТИЕ-СОСТОЯНИЕ-КАЧЕСТВО, III. ОТНОШЕНИЕ (см. Таб. 2). Каждый из классов обладает очень развитой внутренней структурой. В первом классе глаголы дифференцируются по признаку поступательности или направ-

${ }^{2}$ Используется сокращение БТСЛ для работы Бабенко Л. Г. (2009), ред., Большой толковый словарь русских глаголов, Москва. 
ленности движения/перемешения, с учетом исходного или конечного пунктов. Помещение объекта может происходить в определенном месте или вследствие какого-то действия. Помещение объекта принадлежит к классу ДЕЙСТВИЕ/ДЕЯТЕЛЬНОСТЬ, хотя примеры соответствуют на самом деле классам бытийно-локативных глаголов в других трактовках. В области физического воздействия на объект, созидательной / интеллектуальной / речевой / социальной деятельности, дается подробная характеристика глаголов. Во втором классе бытие рассматривается с точки зрения начальной и конечной фазы. Деление так наз. качественного состояния обладает многими дифференцирующими признаками. Третий класс указывает на отношения по признаку их взаимности, подчинения, многосубъектности.

Таб. 2. Семантическая классификация глаголов Л. Г. Бабенко

\begin{tabular}{|c|c|c|}
\hline $\begin{array}{c}\text { 1. ДЕЙСТВИЕ } \\
\text { и ДЕЯТЕЛЬНОСТЬ }\end{array}$ & \begin{tabular}{|c} 
2. БЫТИЕ, СОСТОЯНИЕ, \\
КАЧЕСТВО
\end{tabular} & 3. ОТНОШЕНИЕ \\
\hline $\begin{array}{l}\text { 1.1. Движение } \\
\text { 1.1.1. Поступательное движение } \\
\text { субъекта (глаголы однонаправ- } \\
\text { ленного, разнонаправленного } \\
\text { движения) } \\
\text { 1.1.2. Непоступательное движе- } \\
\text { ние субъекта (глаголы беспоря- } \\
\text { дочного, вращательного и колеба- } \\
\text { тельного движения) }\end{array}$ & $\begin{array}{l}\text { 2.1. Бытие } \\
\text { 2.1.1. Начальная фаза } \\
\text { действия, существова- } \\
\text { ния } \\
\text { 2.1.2. Существование } \\
\text { 2.1.3. Прекращеене бы- } \\
\text { тия }\end{array}$ & $\begin{array}{l}\text { 3.1. Взаимоотношение } \\
\text { 3.1.1 Глагольь взаимосвязи } \\
\text { 3.1.2. Глаголь замены }\end{array}$ \\
\hline $\begin{array}{l}\text { 1.2. Перемещение объекта } \\
\text { 1.2.1. Направленное перемещение } \\
\text { (однонаправленного движения) } \\
\text { 1.2.2. Ненаправленное перемеще- } \\
\text { ние (глаголы кругового и враща- } \\
\text { тельного перемещения) }\end{array}$ & $\begin{array}{l}\text { 2.2. Качественное состо- } \\
\text { яние } \\
\text { 2.2.1. Становление каче- } \\
\text { ства } \\
\text { 2.2.2. Проявление признака } \\
\text { 2.2.3. Глаголь образа } \\
\text { жизни } \\
\text { 2.2.4. Эмочиональное со- } \\
\text { стояние } \\
\text { 2.2.5. Глаголь физиологи- } \\
\text { ческого состояния } \\
\text { 2.2.6. Функииональное } \\
\text { состояние }\end{array}$ & $\begin{array}{l}\text { 3.2. Владение } \\
\text { 3.2.1. Глаголь поиска объ- } \\
\text { екта } \\
\text { 3.2.2. Приобретение } \\
\text { 3.2.3. Глаголь обладания } \\
\text { 3.2.4. Глаголь сохранения } \\
\text { 3.2.5. Глаголь утраты } \\
\text { объекта } \\
\text { 3.2.6. Глаголь лишения } \\
\text { 3.2.7. Глаголь передачи } \\
\text { объекта }\end{array}$ \\
\hline $\begin{array}{l}\text { 1.3. Помещение } \\
\text { 1.3.1. Помещеение объекта } \\
\text { 1.3.2. Глаголь субъектного поме- } \\
\text { щения } \\
\text { 1.3.3. Глаголь включения объек- } \\
\text { та в состав чего-либо } \\
\text { 1.3.4. Покрытие объекта }\end{array}$ & & $\begin{array}{l}\text { 3.3. Межличностные } \\
\text { отношения } \\
\text { 3.3.1. Глаголь эмоциональ- } \\
\text { но-оценочного отношения } \\
\text { 3.3.2. Глаголь внешнего } \\
\text { проявления отношения } \\
\text { 3.3.3. Контакт }\end{array}$ \\
\hline
\end{tabular}


Tаб. 2. Семантическая классификация глаголов Л. Г. Бабенко

\begin{tabular}{|c|c|c|}
\hline $\begin{array}{c}\text { 1. ДЕЙСТВИЕ } \\
\text { и ДЕЯТЕЛЬНОСТЬ }\end{array}$ & \begin{tabular}{|c|} 
2. БЫТИЕ, СОСТОЯНИЕ, \\
КАЧЕСТВО
\end{tabular} & 3. ОТНОШЕНИЕ \\
\hline $\begin{array}{l}\text { 1.4. Физическое воздействие на } \\
\text { объект (нередко разрушительного) } \\
\text { 1.4.1. Глаголы нанесения удара } \\
\text { 1.4.2. Глаголы давления } \\
\text { 1.4.3. Глаголь прикосновения } \\
\text { 1.4.4. Глаголь изменения поло- } \\
\text { жения } \\
\text { 1.4.5. Глаголы очищения и удале- } \\
\text { ния объекта } \\
\text { 1.4.6. Глаголь обработки и рытья } \\
\text { 1.4.7. Повреждение объекта } \\
\text { 1.4.8. Отрицательное воздей- } \\
\text { ствие на объект } \\
\text { 1.4.9. Глаголь избавления } \\
\text { 1.4.10. Глаголь пропитьвьния } \\
\text { 1.4.11. Глаголь соединения } \\
\text { 1.4.12. Глаголь присоединения } \\
\text { 1.4.13. Глаголь разделения } \\
\text { 1.4.14. Глаголь отделения }\end{array}$ & & $\begin{array}{l}\text { 3.4. Социальные отно- } \\
\text { шения } \\
\text { 3.4.1. Глаголь победы } \\
\text { и поражения } \\
\text { 3.4.2. Глаголь принужде- } \\
\text { ния } \\
\text { 3.4.3. Влияние } \\
\text { 3.4.4. Глаголь подчинения } \\
\text { 3.4.5. Глаголь защиты } \\
\text { 3.4.6. Глаголь помощии } \\
\text { 3.4.7. Глаголь обеспечения } \\
\text { 3.4.8. Глаголь разрешения } \\
\text { и запрещения } \\
\text { 3.4.9. Глаголь управления }\end{array}$ \\
\hline $\begin{array}{l}\text { 1.5. Созидательная деятельность } \\
\text { 1.5.1. Создание объекта в резуль- } \\
\text { тате трудовой деятельности } \\
\text { 1.5.2. Приготовление чего-либо } \\
\text { 1.5.3. Глаголь собирания } \\
\text { 1.5.4. Глаголь графической пере- } \\
\text { дачи информации } \\
\text { 1.5.5. Глаголь приведения объек- } \\
\text { та в прежнее состояние }\end{array}$ & & \\
\hline $\begin{array}{l}\text { 1.6. Интеллектуальная деятель- } \\
\text { ность } \\
\text { 1.6.1. Глаголы возможности } \\
\text { и желания } \\
\text { 1.6.2. Глаголы восприятия } \\
\text { 1.6.3. Глаголы понимания } \\
\text { 1.6.4. Глаголы познания } \\
\text { 1.6.5. Глаголь мышления } \\
\text { 1.6.6. Глаголы памяти } \\
\text { 1.6.7. Глаголы воображения } \\
\text { и предположения } \\
\text { 1.6.8. Глаголы сравнения и сопо- } \\
\text { ставления } \\
\text { 1.6.9. Глаголы выбора } \\
\text { 1.6.10. Глаголы решения } \\
\text { 1.6.11. Глаголы определения } \\
\text { 1.6.12. Глаголы проверки }\end{array}$ & & \\
\hline
\end{tabular}


Таб. 2. Семантическая классификация глаголов Л. Г. Бабенко

\begin{tabular}{|c|c|c|}
\hline $\begin{array}{c}\text { 1. ДЕЙСТВИЕ } \\
\text { и ДЕЯТЕЛЬНОСТЬ }\end{array}$ & \begin{tabular}{|c|} 
2. БЫТИЕ, СОСТОЯНИЕ, \\
КАЧЕСТВО
\end{tabular} & 3. ОТНОШЕНИЕ \\
\hline $\begin{array}{l}\text { 1.7. Речевая деятельность } \\
\text { 1.7.1. Глаголы характеризованной } \\
\text { речевой деятельности } \\
\text { 1.7.2. Глаголь речевого сообщения } \\
\text { 1.7.3. Глаголы речевого общения } \\
\text { 1.7.4. Глаголь обращения } \\
\text { 1.7.5. Глаголь речевого воздействия }\end{array}$ & & \\
\hline $\begin{array}{l}\text { 1.8. Социальная деятельность } \\
\text { 1.8.1. Глаголь профессиональ- } \\
\text { но-трудовой деятельности } \\
\text { 1.8.2. Глаголь общественно-по- } \\
\text { литической деятельности } \\
\text { 1.8.3. Глаголь, обозначаюшие дей- } \\
\text { ствия религиозного характера } \\
\text { 1.8.4. Глаголь издательской де- } \\
\text { ятельности и распространения } \\
\text { информации } \\
\text { 1.8.5. Воспроизведение } \\
\text { 1.8.6. Глаголь деятельности по } \\
\text { достиюению иели } \\
\text { 1.8.7. Глаголь осуществления } \\
\text { 1.8.8. Глаголь использования } \\
\text { 1.8.9. Глаголь противодействия } \\
\text { 1.8.10. Глаголь поступка и пове- } \\
\text { дения }\end{array}$ & & \\
\hline $\begin{array}{l}\text { 1.9. Физиологическое действие } \\
\text { 1.9.1. Глагольь физиологического } \\
\text { действия }\end{array}$ & & \\
\hline $\begin{array}{l}\text { 1.10. Звучание } \\
\text { 1.10.1. Глаголь звучания }\end{array}$ & & \\
\hline
\end{tabular}

Источник: БТСЛ.

\section{2. ЦЕЛЬ ИССЛЕДОВАНИЯ}

Целью исследования является проверка возможностей использования вышепредставленных семантических классификаций глагола для автоматического поиска в корпусе как в сложном массиве данных. Указанная задача является непростой, так как среди всех частей речи глагол является самым сложным классом лексем не только с точки зрения набора грамматических категорий, но и с учетом степени полисемии. Поиск глаголов в большом массиве текстов связан с рядом проблем, вызванных его лексическим значением и контекстуальной обусловленностью. 


\section{3. ЭМПИРИЧЕСКИЙ МАТЕРИАЛ}

В качестве эмпирического материала послужил Национальный корпус русского языка (НКРЯ) - самый представительный корпус современного русского языка. Из всех корпусов, входящих в структуру НКРЯ, был выбран Основной подкорпус как наиболее сбалансированный с точки зрения выборки текстов и их жанрово-стилистического разнообразия. Основной подкорпус обладает морфорологической, семантической и метатекстовой разметками. Преимуществом НКРЯ является очень простой интерфейс пользователя. Запрос осуществляется им автоматически путем выбора соответствующих признаков, определенных разметкой. Поиск возможен относительно точных форм, а также слов, соответствующих выбранным грамматическим параметрам. Результаты запроса, содержащие интересующие пользователя единицы, демонстрируются в виде конкорданса (в «обычном формате» и в формате KWIC с указанным словом-ключом посередине).

\section{4. ПРЕДМЕТ ИССЛЕДОВАНИЯ}

Для НКРЯ характерно небольшое количество таксономических классов для каждой из частей речи. Указанный подход объясняется, во-первых, стремлением к быстрой выдаче результатов, во-вторых, упрощением интерфейса пользователя (Кобрицов, Ляшевская, Толдова веб-издание).

Семантическая разметка НКРЯ для глагола разрабатывалась на основе лексической базы данных «Лексикограф-эксперт» в Отделе лингвистических исследований (ОЛИ) ВИНИТИ РАН под руководством Е. В. Падучевой (Кустова, Ляшевская, Падучева, Рахилина 2005: 156). Она позволяет искать словоформы, отвечающие созданной семантической классификации, которая включает характеристику в областях: таксономии, каузации, служебности этой части речи (фазовые и служебные каузативные глаголы), а также словообразования (см. Таб. 3.).

Среди глагольных семантических признаков в НКРЯ выделяются следующие: движение (в том числе изменение положения тела, части тела), помещение объекта, физическое воздействие (в том числе: создание физического объекта, уничтожение), изменение состояния или признака, бытийная сфера (существование / начало существования / прекращение существования), местонахождение (в том числе положение тела в пространстве), контакт и опоpa, посессивная сфера, ментальная сфера, восприятие, психическая сфера (в том числе эмоция, воля), речь, поведение человека, физиологическая сфера, природное явление, звук, свет, запах. 
Таб. 3. Семантические признаки глагола в разметке НКРЯ

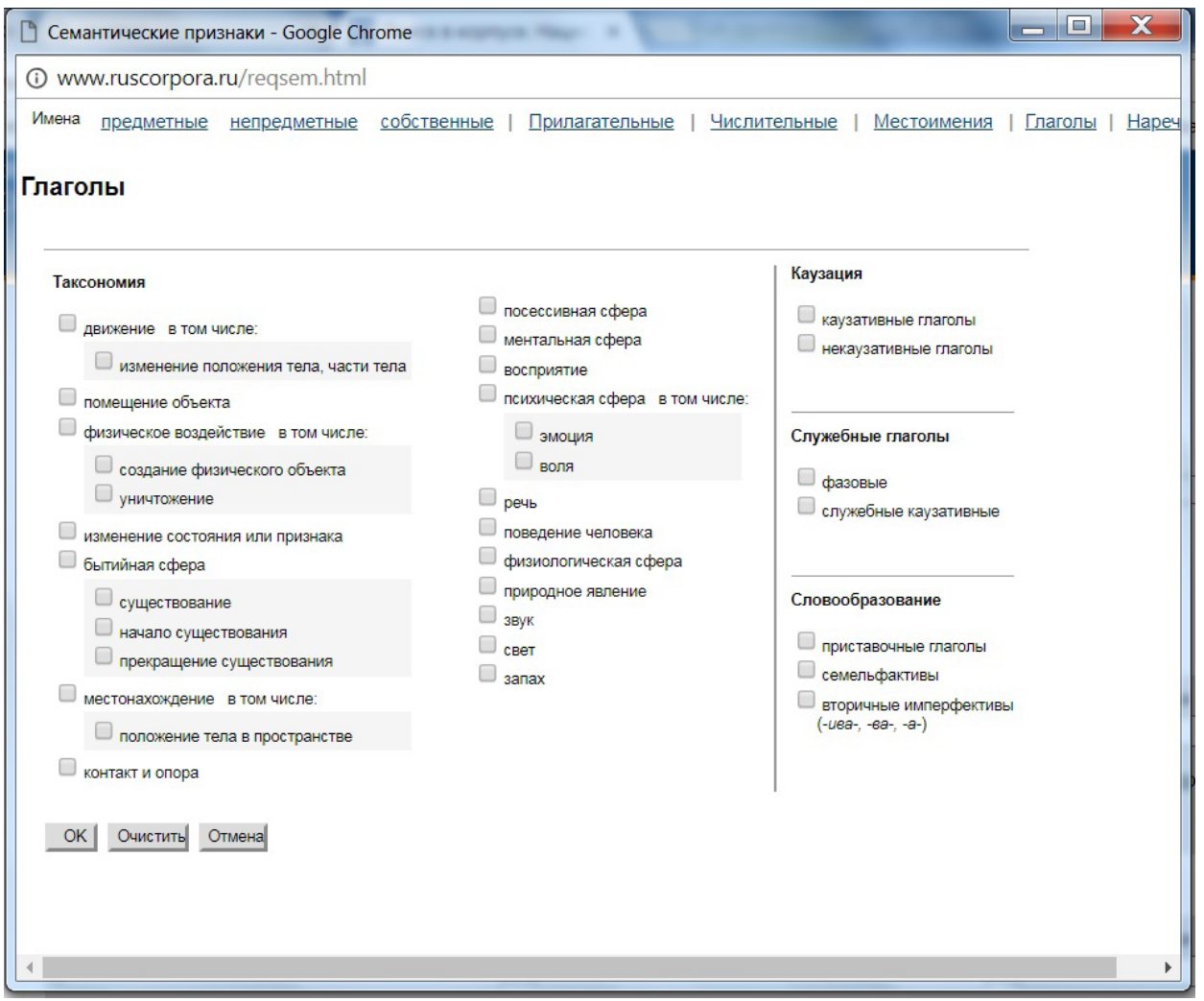

Источник: http://www.ruscorpora.ru/reqsem.html, режим доступа: 11.07.2018.

Принятая в корпусе семантическая классификация глагола лишь частично соответствует представленным раньше разрядам глаголов. По своей номенклатуре она более похожа на классификацию Л. Г. Бабенко (2009), так как здесь отсутствует главное деление глаголов на акциональные и бытийные. Класс «движение (в том числе изменение положения тела, части тела)» - это соединение «класса движение» и «перемещение» по «Большому толковому словарю русских глаголов» (2009). Авторы семантической разметки в НКРЯ разделяют «класс помещение объекта» (глаголы типа положить, упрятать, вложить) и класс «местонахождение (в том числе положение тела в пространстве, - напр. находиться, остаться, располагаться)», которые в других трактовках образуют одну глагольную группу бытийно-локативных глаголов. Класс «физическое воздействие (в том числе: создание физического объекта, уничтожение)», напр. порезать, вылотрошить, замесить соединяет два класса глаголов по словарю Л. Г. Бабенко - «Физическое 
воздействие на объект» и «Созидательную деятельность». В области бытийной сферы (существование / начало существования / прекращение существования), напр. родиться, жить, выделенные три класса совпадают полностью с классификацией «Большого толкового словаря русских глаголов» (2009). Интересным является класс «изменение состояния или признака», который является слишком неопределенным классом лексем, включающим на самом деле практически большинство акциональных глаголов.

Совсем новым, не встречаемым в других трактовках классом лексем является разряд «контакт и опора», напр. касаться, обниматься. Классы типа ментальная сфера (напр. убедиться, судить), восприятие, (напр. рассмотреть, усльшать), психическая сфера (в том числе эмоция, воля, напр. хотеть, любить, скучать), речь (напр. спросить, спорить), поведение человека (напр. кокетничать, капризничать), физиологическая сфера (напр. есть, рыдать) следует причислить к акциональным глаголам. Интересно, что разметка НКРЯ выделяет также классы более подробные с семантической точки зрения, типа: природное явление (напр. дуть, темнеть), звук (напр. звонить, шипеть), свет (напр. сверкать, блестеть), запах (напр. пахнуть, провонять).

\section{5. АНАЛИЗ МАТЕРИАЛА}

Указанную глагольную классификацию следует проверить с точки зрения ее применения для описания глаголов в корпусном материале, что в свою очередь затрагивает проблему создания фильтров для автоматического поиска. По мнению разработчиков семантической разметки, наиболее удобным способом классификации является не древесный, а фасетный принцип: один и тот же глагол может попадать в несколько классов, если это необходимо (Кустова, Ляшевская, Падучева, Рахилина 2005: 159). Указанное мотивируется глагольной неоднозначностью и контекстной обусловленностью. Фасетный принцип позволяет «ориентироваться на весь спектр классификационных возможностей» (там же: 160). Семантические классы НКРЯ характеризируются лингвистической релевантностью, т.е. предполагается, что слова, приналежащие к одному классу, обладают общими особенностями языкового поведения. Итак, глаголы, попадающие в один класс, имеют сходную структуру толкования. «Например, из всех глаголов, в толкование которых входит компонент 'контакт', к классу глаголов контакта относятся только те, у которых этот компонент находится в вершине толкования, ср. касаться, трогать, ухватиться (глаголы контакта)» (там же: 162, курсив - И. К.). 
Снятие глагольной неоднозначности является следующей задачей семантической разметки для глагола в НКРЯ, что можно проиллюстрировать на простых примерах контекстов с глаголом НЫТЬ:

НЫТЬ:

- «звук» Ноет саксофон

- «речь» Не ной, никто тебя не пожалеет

- «физиологическое ощущение» Ноет рука

(Кустова, Ляшевская, Падучева, Рахилина 2005: 167).

Разные значения глагола относят его к разным семантическим классам. Несмотря на факт, что семантические признаки приписываются отдельно каждому значению, при автоматическом поиске в корпусе каждое вхождение слова получает всю совокупность помет, которые есть у разных значений этого слова в словаре. Это создает шум при семантическом поиске. Необходимо убрать «лишние признаки» и у каждого вхождения оставить тот единственный правильный признак, который соответствует его значению в данном контексте. Эта проблема может быть решена двумя способами: снятие неоднозначности вручную или с помощью автоматической программы. Оба способа обладают недостатками. Поэтому Г. И. Кустова, О. Н. Ляшевская, Е. В. Падучева, Е. В. Рахилина в своей научной статье (2005) предлагают некую золотую середину, которая заключается в создании системы фильтров, которые смогут задавать нужные контексты и конструкции, в которых данный глагол употребляется. Фильтры, разработанные опытными программистами в сотрудничестве с лингвистами, позволят снимать лексическую неоднозначность автоматически (там же: 169). Итак, глагол довести получает в корпусе двойную помету: входит в класс «движение» и «воздействие на человека», напр. довести до подъезда, довести до бешенства (Кустова, Ляшевская, Падучева, Рахилина 2005: 170). Указанную неоднозначность можно снять, задавая ограничение для существительного, которое входит с указанным глаголом в синтаксические отношения: «довести +до+сущ.: род.п. \& эмоциональное состояние или проявление» (там же: 170).

Не только семантическая неоднозначность глагола является проблемой, требующей решения в НКРЯ. Еще более существенной является отсутствие семантической пометы в корпусе для некоторых глаголов.

В качестве примера и одновременно объектом настоящего исследования послужили глаголы, определяемые в литературе вопроса как «вторичные имперфективы». Это особая группа глаголов, обладающих приставочно-суффиксальной морфематикой. На основании проведенного корпусного анализа следует утверждать, что общее количество указанных глаголов, полученных по запросу «V d:impf, d:impf» составляет в корпусе 3505 лемм, из чего оши-

3 См. также Kozera I. 2018, Семантика и прагматика вторичной имперфективации в современном русском языке на основании корпусного анализа, Kraków. 
бочными были признаны 1182 леммы, остались 2323 правильные леммы вторичных имперфективов. Найденные глаголы были в дальнейшем разделены в зависимости от признаков, выделенных семантической раметкой НКРЯ в рамках таксономии. Анализ полученных данных позволил заметить существенные проблемы, вытекающие из использования автоматической семантической разметки. В частности было выявлено, что не все глаголы обладают в корпусе семантической характеристикой, получая помету «disamb» (от англ. «disambiguation»). Одна треть всех найденных в корпусе вторичных имперфективов не была заранее причислена к какому-нибудь семантическому классу. В то же время остальная часть материала могла одновременно подходить для нескольких семантических типов, иногда схожих в смысловом плане, напр. вдалбливать («физическое воздействие», «эмоция»), взвешивать («помещение объекта», «эмоция»), взрывать («физическое воздействие», «уничтожение», «прекращение существования», «эмоция»), вслушиваться («восприятие», «эмоция»), вылмачивать («изменение состояния или признака», «эмоция», «физическое воздействие») и т.п. Указанная пересекаемость глагольных типов вытекает из сложности глагольной семантики, для которой характерно наличие общего значения и его специфических (часто переносных) вариантов. Это обеспечивает возможность перехода из дословного (первичного) значения физического процесса к вторичному (метафорическому, отвлеченному). Таким образом, подтверждается концепция Л. М. Васильева, согласно которой семема обладает ядерным и периферийным значениями (Васильев 1981: 23).

Список глаголов (см. Таб. 4), обладающих семантической определенностью составил 1667 лемм, в числе которых 251 глагол подходит для нескольких типов, выделенных в корпусной разметке. Остальная часть материала - 656 лемм обладает пометой «disamb», обозначающей семантическую неоднозначность.

Таб. 4. Типология вторичных имперфективов по данным НКРЯ

\begin{tabular}{|l|c|l|}
\hline $\begin{array}{c}\text { СЕМАНТИЧЕСКИЙ ТИП } \\
\text { ГЛАГОЛА } \\
\text { (семантическая разметка НКРЯ) }\end{array}$ & $\begin{array}{c}\text { КОЛИЧЕСТВО } \\
\text { ЛЕММ }\end{array}$ & \multicolumn{1}{|c|}{ ПРИМЕРЫ } \\
\hline Движение & 238 & перекидывать, накачивать \\
\hline $\begin{array}{l}\text { изменение положения тела, } \\
\text { части тела }\end{array}$ & 15 & $\begin{array}{l}\text { присаживаться, вытягивать, } \\
\text { осаживать }\end{array}$ \\
\hline Помещение объекта & 25 & $\begin{array}{l}\text { завешивать, нанизывать, } \\
\text { вкладывать }\end{array}$ \\
\hline Физическое воздействие & 258 & $\begin{array}{l}\text { пробивать, выстукивать, } \\
\text { спаривать, вымораживать }\end{array}$ \\
\hline ・ создание физического объекта & 42 & $\begin{array}{l}\text { подиивать, заваривать, } \\
\text { перестраивать, перевязывать }\end{array}$ \\
\hline
\end{tabular}


Таб. 4. Типология вторичных имперфективов по данным НКРЯ

\begin{tabular}{|c|c|c|}
\hline $\begin{array}{c}\text { СЕМАНТИЧЕСКИЙ ТИП } \\
\text { ГЛАГОЛА } \\
\text { (семантическая разметка НКРЯ) }\end{array}$ & $\begin{array}{c}\text { КОЛИЧЕСТВО } \\
\text { ЛЕММ }\end{array}$ & ПРИМЕРЫ \\
\hline - уничтожение & 6 & $\begin{array}{l}\text { отстреливать, вытаптыввать, } \\
\text { взрьвать, застреливать }\end{array}$ \\
\hline $\begin{array}{l}\text { Изменение состояния или } \\
\text { признака }\end{array}$ & 81 & $\begin{array}{l}\text { обогревать, досушивать, } \\
\text { одуревать, ослабевать }\end{array}$ \\
\hline Бытийная сфера & 0 & - \\
\hline - существование & 4 & $\begin{array}{l}\text { вылживать, проживать, } \\
\text { истлевать, дотлевать }\end{array}$ \\
\hline - начало существования & 0 & - \\
\hline • прекращение существования & 19 & $\begin{array}{l}\text { вымирать, убивать, оканчивать, } \\
\text { доживать }\end{array}$ \\
\hline Местонахождение & 25 & рассиживаться \\
\hline • положение тела в пространстве & 0 & - \\
\hline Контакт и опора & 0 & - \\
\hline Посессивная сфера & 48 & $\begin{array}{l}\text { охватывать, завладевать, } \\
\text { раскрадывать }\end{array}$ \\
\hline Ментальная сфера & 32 & $\begin{array}{l}\text { осмиссливать, распознавать, } \\
\text { продумьввать, уразумевать }\end{array}$ \\
\hline Восприятие & 33 & $\begin{array}{l}\text { выслушивать, отслеживать, } \\
\text { снюхиваться, взглядывать }\end{array}$ \\
\hline Психическая сфера & 2 & взбадривать, претерпевать \\
\hline • эмоция & 672 & $\begin{array}{l}\text { высмеивать, вынучивать, } \\
\text { очаровывать }\end{array}$ \\
\hline • воля & 0 & - \\
\hline Речь & 83 & $\begin{array}{l}\text { приговаривать, прикрикивать, } \\
\text { упрачивать }\end{array}$ \\
\hline Поведение человека & 6 & подлизываться \\
\hline Физиологическая сфера & 48 & пережевывать, запивать \\
\hline Природное явление & 5 & $\begin{array}{l}\text { обвевать, накрапьвать, навевать, } \\
\text { покрапьвать }\end{array}$ \\
\hline Звук & 20 & $\begin{array}{l}\text { подсвистывать, отстукивать, } \\
\text { обзванивать }\end{array}$ \\
\hline Свет & 4 & $\begin{array}{l}\text { отсвечивать, подсвечивать, } \\
\text { просвечивать }\end{array}$ \\
\hline \multirow[t]{2}{*}{ Запах } & 1 & запахивать \\
\hline & 1667 & \\
\hline
\end{tabular}

Источник: Kozera 2018: 146-147. 
Указанное свидетельствует о том, что фильтры для снятия семантической неоднозначности все еще не готовы и пользователь корпуса по-прежнему получает полный спектр классификационных возможностей.

\section{6. ВЫВОдЫ}

Семантическую классификацию глаголов в функциональном аспекте разрабатывают многие ученые. Большую ценность имеют работы Э. В. Кузнецовой и ее школы, результатом чего является «Большой толковый словарь русских глаголов» под редакцией Л. Г. Бабенко (2009). Следует обратить внимание на работы Л. М. Васильева $(1981,1990)$, Г. А. Золотовой (1982) и А. М. Чепасовой, И. Г. Казачук (2007). Способ описания глагольной семантики становится все еще существенным, если его применить к автоматическому поиску в корпусном материале. Снятие семантической неоднозначности с помощью фильтров потребует значительных усилий со стороны лингвистов и программистов, в связи с чем представляет собой следующую задачу разработчиков НКРЯ на пути к усовершенствованию лингвистического описания русского языка в корпусе. Анализ семантического описания особенной группы глаголов - так наз. вторичных имперфективов, которые в корпусе иногда вообще не получают никакой семантической пометы, указывает на существенные недостатки НКРЯ и необходимость усовершенствования семантической разметки.

\section{Библиография}

Babenko L. G. (1999), (red.), Tolkovyy tematicheskiy slovar' russkikh glagolov. Ideograficheskoe opisanie. Angliyskie ekvivalenty. Sinonimy. Antonimy, Moskva. / Бабенко Л. Г. (1999), (ред.), Толковый тематический словарь русских глаголов. Идеографическое описание. Английские эквиваленты. Синонимы. Антонимы, Москва.

Babenko L. G. (2009), (red.), Bol'shoy tolkovyy slovar' russkikh glagolov, Moskva (sokrashchenie: БТСЛ) / Бабенко Л. Г. (2009), (ред.), Большой толковый словарь русских глаголов, Москва. (сокращение: БТСЛ)

Drozd A. F. (2013), Semanticheskie klassy glagolov - proizvodyashchikh baz imen deyatelya $v$ sovremennom angliyskom yazyke, [v:] Aktual'nye voprosy filologii, pedagogiki i metodiki prepodavaniya inostrannykh yazykov: sbornik nauchnykh trudov, Vyp. 1, s. 35-45. I Дрозд А. Ф. (2013), Семантические классы глаголов - производящих баз имен деятеля в современном английском языке, [в:] Актуальныле вопросы филологии, педалгогики и методики преподавания иностранных языков: сборник научных трудов, Вып. 1, с. 35-45.

Giro-Veber M. (1990), Vid i semantika russkogo glagola, "Voprosy yazykoznaniya", $\mathrm{Nr} 2$, s. 102-112, (online:) http://www.philology.ru/linguistics2/giro-veber-90.htm, rezhim dostuра: 06.08.2018. / Гиро-Вебер М. (1990), Вид и семантика русского глагола, „Вопросы языкознания", № 2, с. 102-112, (online:) http://www.philology.ru/linguistics2/giro-veber-90. htm, режим доступа: 06.08.2018. 
Kobritsov B. P., Lyashevskaya O. N., Toldova C. Yu., Snyatie semanticheskoy mnogoznachnosti glagolov s ispol'zovaniem modeley upravleniya, izvlechennykh iz elektronnykh tolkovykh slovarey, (online:) http://download.yandex.ru/IMAT2007/kobricov.pdf, rezhim dostupa: 11.07.2018. / Кобрицов Б. П., Ляшевская О. Н., Толдова С. Ю., Снятие семантической многозначности глаголов с использованием моделей управления, извлеченных из электронных толковых словарей, (online:) http://download.yandex.ru/IMAT2007/kobricov.pdf, режим доступа: 11.07.2018.

Kozera I. (2018), Semantika i pragmatika vtorichnoy imperfektivatsii v sovremennom russkom yazyke na osnovanii korpusnogo analiza, Kraków. / Kozera I. (2018), Семантика и прагматика вторичной имперфективации в современном русском языке на основании корпусного анализа, Kraków.

Kustova G. I., Lyashevskaya O. N., Paducheva E. V., Rakhilina E. V. (2005), Semanticheskaya razmetka leksiki v Natsional'nom korpuse russkogo yazyka: printsipy, problemy, perspektivy, [v:] Natsional'nyy korpus russkogo yazyka: 2003-2005. Rezul'taty i perspektivy, s. 155-174, (online:) http://ruscorpora.ru/sbornik2005/10kustova.pdf, rezhim dostupa: 11.07.2018. / Кустова Г. И., Ляшевская О. Н., Падучева Е. В., Рахилина Е. В. (2005), Семантическая разметка лексики в Национальном корпусе русского языка: принципы, проблемы, перспективы, [в:] Национальный корпус русского языка: 2003-2005. Результаты и перспективы, с. 155-174, (online:) http://ruscorpora.ru/sbornik2005/10kustova.pdf, режим доступа: 11.07.2018.

Kuznetsova E. V. (1988), Leksiko-semanticheskie gruppy russkikh glagolov, Sverdlovsk. / Кузнецова Э. В. (1988), Лексико-семантические группы русских глаголов, Свердловск.

Kuznetsova E. V. (1989), Leksiko-semanticheskie gruppy russkikh glagolov, Irkutsk. / Кузнецова Э. В. (1989), Лексико-семантические группы русских глаголов, Иркутск.

Vasil'ev L. М. (1981), Semantika russkogo glagola, Moskva. / Васильев Л. М. (1981), Семантика русского глагола, Москва.

Vasil'ev L. М. (1990), Sovremennaya lingvisticheskaya semantika, Moskva. / Васильев Л. М. (1990), Современная лингвистическая семантика, Москва.

Zolotova G. A. (1982), Kommunikativnye aspekty russkogo sintaksisa, Moskva. / Золотова Г. А. (1982), Коммуникативные аспекты русского синтаксиса, Москва.

\title{
Istochnik empiricheskogo materiala
}

Natsional'nyy korpus russkogo yazyka (НКРЯ) - http://www.ruscorpora.ru/, rezhim dostupa: 11.07.2018. / Национальный корпус русского языка (НКРЯ) — http://www.ruscorpora.ru/, режим доступа: 11.07.2018.

\author{
Izabela Kozera
}

\section{SEMANTIC CHARACTERISTICS OF THE RUSSIAN VERB BASED ON RNC}

(Summary)

The paper is devoted to the study of the verbal semantic parameters used in the Russian National Corpus (RNC). The author analyzes the lexical-semantic groups of verbs and the problems of creating filters for automatically searching for a selected group (so-called secondary imperfectives). A detailed analysis of the corpus results revealed the problem with the semantic annotation of the $\mathrm{RNC}$ and the need for its improvement. 


\section{СЕМАНТИЧЕСКАЯ ХАРАКТЕРИСТИКА РУССКОГО ГЛАГОЛА ПО ДАННЫМ НКРЯ}

(Резюме)

Настоящая статья посвящена семантическим параметрам, используемым при поиске глаголов в Национальном корпусе русского языка (НКРЯ). Автор анализирует лексикально-семантическую группу глаголов и проблемы образования фильтров, применяемых к автоматическому поиску особенной группы глаголов (так наз. вторичных имперфективов). Анализ их семантического описания указывает на существенные недостатки НКРЯ и необходимость усовершенствования семантической разметки. 